\title{
Rare earth elements compositions of Setouchi high Mg andesites (HMAs) and basalt; an implication for a mantle compositional shift beneath the SW Japan arc during the Japan Sea opening
}

\author{
Gen Shimoda ${ }^{1,2}$, Masahiro Nagai ${ }^{3}$ and Yuichi Morishita ${ }^{2}$
}

\begin{abstract}
Gen Shimoda, Masahiro Nagai ${ }^{1}$ and Yuichi Morishita (2004) Rare earth elements compositions of Setouchi high Mg andesites (HMAs) and basalt; an implication for a mantle compositional shift beneath the SW Japan arc during the Japan Sea opening. Bull. Geol. Surv. Japan, vol. 55 (1/2), 3138,3 figs, 2 tables,.

Abstract: In order to evaluate the effect of the Japan Sea opening upon the mantle wedge beneath the SW Japan arc, rare earth elements (REE) compositions were determined for primitive high magnesian andesites (HMAs) and a basalt from the Setouchi volcanic belt in the SW Japan arc. The older HMA from the Osaka area (13.9 Ma) has higher light rare earth elements (LREE) and lower heavy rare earth elements (HREE) concentrations than the younger HMA from the Shodo-Shima area (12.7 Ma). To explain these REE patterns, mixing calculations were conducted. The results show that $30 \sim 70 \%$ of the asthenospheric component (MORB source like materials) and $70 \sim 30 \%$ of the pre-existing mantle, which is estimated from the Osaka HMA, can account for the REE patterns of the Shodo-Shima HMA and basalt. This result may suggest a replacement of a pre-existing mantle wedge by an asthenospheric component, which is related to the Japan Sea opening.
\end{abstract}

Keywords: REE, Japan Sea opening, Setouchi high Mg andesites (HMAs), Shodo-Shima

\section{Introduction}

The Japan Sea is a backarc basin situated behind the SW Japan arc. This backarc basin was formed during the middle Miocene following the rapid rotational movement of the SW Japan arc sliver (Otofuji et al., 1985, 1991; Kaneoka et al., 1990, 1992). This megatectonic event caused the young Philippine Sea plate subduction beneath the SW Japan arc to induce magmatism in the Setouchi area and Outer zone area in SW Japan (Shinjoe, 1997; Tatsumi et al., 2001).

These magmatisms are considered to be related to the high temperature condition of the mantle wedge, which was attained by hot plate subduction and backarc spreading (Tatsumi and Maruyama, 1989). From this viewpoint, the contribution of the hot plate subduction to the magmatisms has been intensively studied (e.g., Shimoda et al., 1998, 2003; Shimoda and Tatsumi, 1999). Although it has been considered that the Japan Sea opening was essential for the magmatic processes in SW Japan, the geochemical effect of the Japan Sea opening upon the mantle wedge has been less studied.

To examine this effect, we analyzed REE compositions of the primitive Setouchi volcanic rocks, i.e.,
HMAs and a basalt because these rocks are considered to be directly derived from the upper mantle (Tatsumi, 1981, 1982) suggesting minimal effects of crustal contamination and crystal fractionation. Since these two types of primitive rocks were erupted simultaneously in a small area (Shodo-Shima Island), these rocks would give tight constrains on the mantle wedge. In addition, the origin of outer zone granitic rocks has been explained by the mixing of mantle derived HMA with sedimentary rocks of Shimanto belt (Shinjoe, 1997). Thus to clarify the origin of the HMAs and basalt is important to understand the magmatic processes in the SW Japan arc during the middle Miocene. In this paper, we will discuss the effect of the Japan Sea opening upon the mantle wedge on the basis of the REE concentrations of the Setouchi volcanic rocks.

\section{Tectonic setting}

The Setouchi volcanic belt was built along the Nankai Trough in the SW Japan arc, where the Eurasian plate overlies the Philippine Sea plate. It forms a narrow zone for about $600 \mathrm{~km}$ (Fig. 1). The K-Ar ages and paleomagnetic data have revealed that the SW Japan arc sliver has rotated clockwise about $60^{\circ}$ (Otofuji et al.,

\footnotetext{
${ }^{1}$ Graduate School of Human and Environmental Sciences, Kyoto University, Kyoto, 606-8501, Japan.

${ }^{2}$ Geological Survey of Japan, AIST, Central 7, Higashi 1-1-1, Tsukuba 305-8567, Japan.

${ }^{3}$ The University of Human and Environments, Okazaki 444-3505, Japan.
} 
$1985,1991)$ in the late stage of the Japan Sea opening (Tamaki et al., 1992; Tamaki, 1995). This rotational movement caused the young Philippine Sea plate subduction (15 $26 \mathrm{Ma}$; Okino et al., 1994) and induced the Setouchi magmatism around $13 \mathrm{Ma}$ (Tatsumi et al., 2001). It has been further suggested that the magmatism in the Osaka area preceded that in the Shodo-Shima area (Tatsumi et al., 2001).

\section{Samples}

Three volcanic rocks, i.e., SD261, SDSYB from the Shodo-Shima area and TGI-5 from the Osaka area, were selected for the REE analyses from ca. 60 samples reported in Ishizaka and Tatsumi, (1985) and Shimoda et al., (1998) because of their primitive features. Highpressure melting experiments have shown that the HMA SD261 and basalt SDSYB were directly derived from the upper mantle (Tatsumi, 1982). Furthrmore, it was suggested that residual phase assemblages of these magmas were lherzolitic (Tatsumi, 1982). The HMA TGI-5 was inferred to be produced by direct partial melting of mantle peridotite with a harzburgitic residual phase assemblage (Tatsumi, 1981). Unfortunately, there is no primitive basalt in the Osaka area. The less-fractionated characteristics both for the HMAs and basalt including the chemical compositions of these magmas that can coexist with mantle peridotites indicate a minimal effect of crustal contamination and crystal fractionation. The K-Ar ages of SD261, SDSYB and TGI5 were $12.7 \pm 0.3,12.5 \pm 0.3$ and $13.9 \pm 0.8 \mathrm{Ma}$, respectively (Tatsumi et al., 2001). Since these three rocks have been intensively studied, they are the most suitable samples for this study.

\section{Analytical procedures}

The analytical procedure was similar to that of Iwasaki and Haraguchi (1988). About $500 \mathrm{mg}$ of powdered rock sample was dissolved in a mixture of $10 \mathrm{ml}$ of nitric acid (14 M), $10 \mathrm{ml}$ of hydrofluoric acid (22 $\mathrm{M})$ and $2.5 \mathrm{ml}$ of perchloric acid $(10 \mathrm{M})$ in a Teflon vial on a hot plate at $170{ }^{\circ} \mathrm{C}$ for a day and evaporated to dryness. The residue was dissolved in $10 \mathrm{ml}$ of $6 \mathrm{M}$ hydrochloric acid and diluted to $150 \mathrm{ml}$ with deionized water and added $5 \mathrm{ml}$ of $4 \% \mathrm{Ca}$ solution $\left(\mathrm{CaCl}_{2}\right.$ in $0.4 \mathrm{M} \mathrm{HCl}$ ). Two grams of oxalic acid dehydrate was added to this solution, and the $\mathrm{pH}$ was adjusted to 3.75 with an ammonia solution. The precipitate was filtered by an ashless filter paper and ignited to convert the oxides. The residue was dissolved by $25 \mathrm{ml}$ of $2 \mathrm{M}$ nitric acid and diluted to $50 \mathrm{ml}$ with deionized water. The solution was loaded onto a column $(1 \mathrm{~cm}$ ID X $20 \mathrm{~cm} \mathrm{H}$ ) packed with a Dowex AG 50W-X8 100200 mesh, which was equilibrated with $1 \mathrm{M}$ nitric acid. The column was washed with $130 \mathrm{ml}$ of $2 \mathrm{M}$ nitric

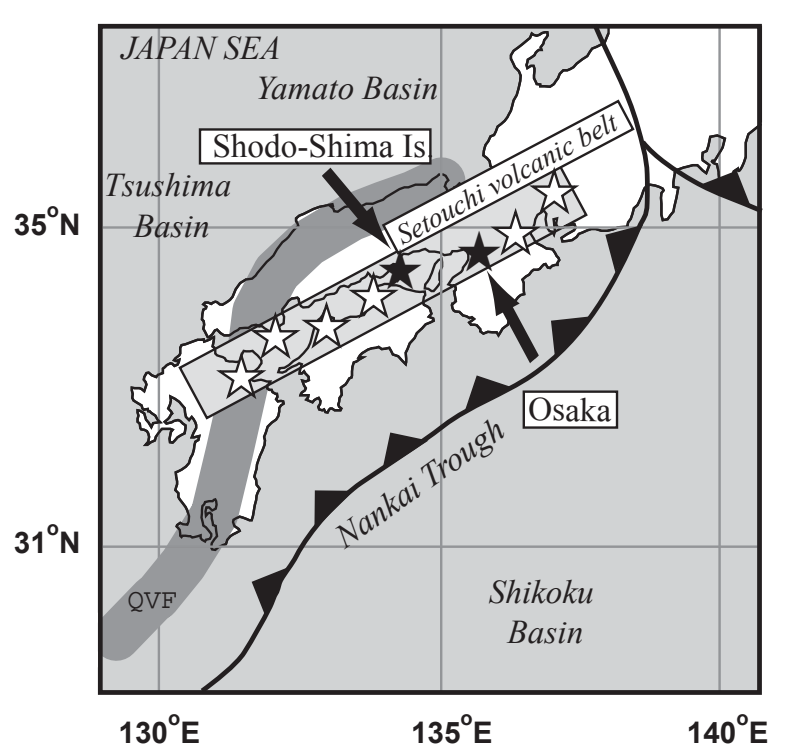

Fig. 1. Distribution of the Setouchi volcanic rocks (stars). Solid stars indicate the Shodo-Shima and Osaka areas. QVF means Quaternary volcanic front.

acid to remove major elements, and REE were eluted with $100 \mathrm{ml}$ of $6 \mathrm{M}$ nitric acid. Three $\mathrm{ml}$ of $10 \mathrm{M}$ perchloric acid was added to the solution and evaporated to dryness. The residue was dissolved in $2.5 \mathrm{ml}$ of $6 \mathrm{M}$ hydrochloric acid and diluted with deionized water to $10 \mathrm{ml}$. The REE concentrations were determined with an inductively-coupled plasma atomic emission spectrometer (ICP-AES; Seiko Instruments Inc. SPS 4000 at Kyoto University).

\section{Result}

The REE concentrations and CI-chondrite normalized REE patterns for the Setouchi volcanic rocks are given in Table 1 and Fig. 2. Ishizaka and Tatsumi (1985) also reported the REE compositions of these HMA and basalt determined with instrumental neutron activation analysis (INAA), but analyzed elements were limited. Thus the obtained REE patterns were rather ambiguous and difficult to precisely discuss the origin of these rocks. The REE data determined with INAA for the same samples are also shown in Table 1. Both studies obtained identical values suggesting the reliability of our analyses.

All of the Setouchi samples have LREE enrichment compared with HREE (Fig. 2). Comparing the TGI-5 (Osaka HMA) with the SD261 (Shodo-Shima HMA), the former has higher LREE and lower HREE concentrations than the latter. The SDSYB (Shodo-Shima basalt) has a steeper REE pattern and higher REE concentrations than the HMA from the same area (Fig. 2). 
Table 1. REE compositions of the Setouchi volcanic rocks

\begin{tabular}{|c|c|c|c|c|c|c|}
\hline & \multirow{2}{*}{\multicolumn{2}{|c|}{$\frac{\text { Osaka }}{\text { TGI-5 }}$}} \\
\hline \multicolumn{5}{|c|}{ Location $\frac{\text { Shodo-Shima }}{\text { SDSYB }^{1}}$} & & \\
\hline & this work & $\mathrm{I} \& \mathrm{~T}^{2}$ & this work & $I \& T^{2}$ & this work & $I \& T^{2}$ \\
\hline Rock type & Basalt & & HMA & & HMA & \\
\hline $\mathrm{La}(\mathrm{ppm})$ & 10.3 & 10.6 & 8.6 & 8.65 & 12.0 & 12.2 \\
\hline $\mathrm{Ce}$ & 24.3 & 23.7 & 18.7 & 20.5 & 21.5 & 22.5 \\
\hline $\mathrm{Nd}$ & 9.1 & & 9.5 & & 10.6 & \\
\hline $\mathrm{Sm}$ & 3.3 & 3.59 & 2.4 & 2.51 & 2.2 & 2.37 \\
\hline $\mathrm{Eu}$ & 1.1 & 1.18 & 0.8 & 0.82 & 0.6 & 0.69 \\
\hline Gd & 3.5 & & 2.6 & & 2.0 & \\
\hline Dy & 3.2 & & 2.6 & & 1.9 & \\
\hline Er & 1.7 & & 1.5 & & 1.1 & \\
\hline $\mathrm{Yb}$ & 1.4 & 1.85 & 1.4 & 1.49 & 1.1 & 1.49 \\
\hline
\end{tabular}

\begin{tabular}{llll}
\multicolumn{5}{l}{ CI-chondrite normalized 4} \\
\hline La & 43 & 36 & \\
$\mathrm{Ce}$ & 40 & 31 & 31 \\
$\mathrm{Nd}$ & 20 & 20 & 23 \\
$\mathrm{Sm}$ & 22 & 15 & 14 \\
$\mathrm{Eu}$ & 19 & 14 & 10 \\
$\mathrm{Gd}$ & 17 & 13 & 9.7 \\
$\mathrm{Dy}$ & 13 & 10 & 7.5 \\
$\mathrm{Er}$ & 10 & 9.1 & 6.6 \\
$\mathrm{Yb}$ & 8.2 & 8.2 & 6.5 \\
\hline
\end{tabular}

${ }^{1}$ SDSYB equivalent to SD438 in Tatsumi (1982)

${ }^{2}$ Data from Ishizaka and Tatsumi (1985) detremined with INAA

${ }^{3}$ TGI-5 equivalent to TGI in Tatsumi (1981)

${ }^{4}$ Normalized CI values in Sun S.-s., McDonough (1989)

\section{Discussion}

\section{Source compositional difference}

Based on the residual phase assemblages, it has been inferred that the degree of partial melting of TGI-5 (Osaka HMA) is higher than that of SD261 (ShodoShima HMA) (Tatsumi, 1981, 1982). Although the residual phase assemblages of the Osaka HMA may also be explained by a previous melt extraction, the process selectively extracts LREE and can not explain the steeper REE pattern of the Osaka HMA.

The higher degree of partial melting decreases the incompatible element concentrations in the magma. Therefore higher LREE concentrations of TGI-5 relative to SD261 firmly contradict the higher degree of partial melting. Because of the primitive features of TGI-5 and SD261, effects of the crustal contamination and crystal fractionation are negligible. Thus the difference of REE patterns between the Osaka and ShodoShima HMAs can be attributed to the source compositional difference.

\section{Can primitive HMAs represent the mantle compo- sitions?}

It has been suggested that the origin of outer zone granitic rocks was inferred to be the products of a mixture of the mantle derived HMA and Shimanto sedimentary rocks (Shinjoe, 1997). If this is the case, the mantle derived primitive rocks in the Setouchi area and

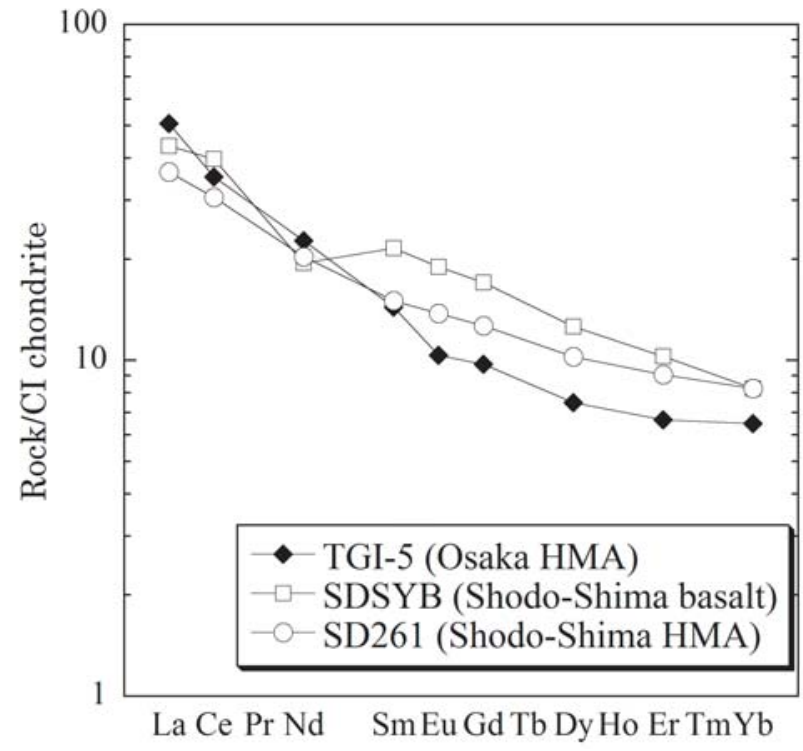

Fig. 2. The CI-chondrite normalized REE patterns of primitive Setouchi HMAs and basalt. The REE concentrations were normalized by the values in Sun and McDonough (1989).

outer zone have similar geochemical features. This similarity may suggest that the mantle composition beneath the area does not vary significantly because the chemical features of primitive rocks depend on the mantle composition.

The selection of the most primitive rock in a particular area is essential to estimate the mantle composition because crustal contamination and magmatic evolution processes could change the magma composition. As a result, we selected most primitive rocks in the Shodo-Shima and Osaka areas as representative samples of each area based on high pressure experiments, $\mathrm{Fe} / \mathrm{Mg}$ ratios, $\mathrm{Mg}$ concentrations and $\mathrm{Pb}, \mathrm{Nd}$ and Sr isotopic compositions (Tatsumi, 1981, 1982; Shimoda et al., 1998). Since the selected rocks (SD261, SDSYB and TGI-5) have chemical compositions that can coexist with mantle peridotites (Tatsumi, 1981, 1982), these rocks might directly be derived from the mantle. Thus the mantle compositions estimated with these rocks should be accurate compared to those estimated with other rocks, even if the estimations are conducted using a large number of rocks from the extensive area in the SW Japan arc. Thus we estimate the mantle composition using SD261, SDSYB and TGI-5.

\section{Heat transportation}

It has been suggested that an unusual high temperature condition was attained beneath SW Japan during the Setouchi magmatism (Tatsumi and Maruyama, 1989). This high temperature condition is inferred to be related to the young plate subduction and backarc opening. In addition, the SW Japan arc rotated during the Japan Sea opening. These conditions imply that 
asthenospheric materials were actively/passively injected beneath the Japan Sea. Although Yamato Basin, which is a backarc basin behind the SW Japan arc, is considered to be produced by crustal thinning (Tamaki, 1995), there were volcanic activities in the Yamato Basin during the Japan Sea opening (Kaneoka et al., 1990). Therefore the asthenospheric materials should also intrude beneath the Yamato Basin during the Japan Sea opening.

It was shown that both the young plate subduction and backarc opening would be essential for the Setouchi magmatism (Tatsumi and Maruyama, 1989). This notion suggests that heat from the backarc basin should play an essential role to induce the Setouchi magmatism. It has been reported that thermal diffusivity for the upper mantle is $4 \sim 8 \times 10^{-7}$ (Tommasi et al., 2001). Assuming that the distance of heat transfer is $100 \mathrm{~km}$ (distance between the Setouchi region and Japan Sea coast), it takes ca. $8 \times 10^{8} \mathrm{yr}$ for heat transportation. Consequently, thermal diffusion was not an appropriate mechanism to raise the temperature beneath the Setouchi region because SW Japan drifted ca. $600 \mathrm{~km}$ (Otofuji et al., 1985). On the other hand, it is reasonable to assume that asthenospheric flow drifted to the SW Japan arc and raised the temperature beneath the Setouchi region because this mechanism can directly transport heat from the backarc area to the Setouchi area. Furthermore, this mechanism can explain the coincidence of the Japan Sea opening, SW Japan rotation and Setouchi magmatism. Although the heat from the Philippine Sea plate alone might explain the origin of the Setouchi magmatism, coincidence of backarc spreading and young plate subduction during the forearc magmatism in other subduction zones may suggest that the heat from the backarc opening would be essential for forearc magmatism (Tatsumi and Maruyama, 1989). Thus we discuss the origin of the Setouchi magmatism based on this assumption.

\section{Origin of source mantle difference}

A possible explanation, which is responsible for the source compositional difference, is the mantle heterogeneity or mantle compositional change by an asthenospheric injection during the Japan Sea opening. Although the former cannot be denied, the mechanism would be rather ad hoc and cannot logically explain the difference in REE compositions of these areas. On the other hand, the mantle compositional change by the asthenospheric flow can consistently explain the relationship between the high temperature condition beneath the SW Japan arc and compositional difference between the HMAs.

In order to examine the chemical effect of the asthenospheric flow upon the mantle composition, mixing calculations were conducted. To estimate the
REE composition of the asthenospheric material, primitive basalt from the Yamato basin was selected among the basalts from the Japan, Yamato and Tsusima Basins based on $\mathrm{Fe} / \mathrm{Mg}$ ratios, $\mathrm{Mg}$ concentrations and $\mathrm{Pb}$, $\mathrm{Nd}$, and $\mathrm{Sr}$ isotopic compositions. To calculate the REE composition of the mantle without the effect of the asthenospheric flow (pre-existing mantle composition), HMA TGI-5 was selected.

To estimate the REE composition for each magma source material, the information of the degree of partial melting was indispensable. Many high pressure experiments on lherzolites suggest that about $20 \%$ partial melting appeared to be required to produce primitive mid-ocean ridge basalts (MORB) (e.g., Wilson, 1989). Thus we assumed the degree of partial melting of the primitive basalt from the Yamato basin was $20 \%$.

For the Setouchi HMAs, the available constraints for the degree of partial melting are the residual phase assemblages, namely, the residual phase assemblage of the Osaka HMA and Shodo-Shima HMA was hartzburgitic and lherzolitic, respectively (Tatsumi, 1981, 1982). These constraints indicate that the ShodoShima HMA would have the least degree of partial melting among the Osaka HMA, Shodo-Shima HMA and Yamato Basin basalt. In addition, it is believed that the degree of partial melting of magmas is usually 10 $\sim 20 \%$. Thus we assumed the degree of partial melting of the Shodo-Shima HMA to be $10 \%$.

It has been reported the degree of partial melting that changes the residual phase assemblage from lherzolite to hartzburgite was $25 \%$ at $20 \mathrm{kbar}$ and $45 \%$ at 35 kbar (Mysen and Kushiro, 1977). Since final equilibration between the Setouchi HMAs and mantle peridotite was inferred to be $10 \mathrm{kbar}$ (Tatsumi, 1981, 1982), the degree of melting that changes the residual phase assemblage should be less than $25 \%$. Considering that the degree of partial melting of the Osaka HMA might be lower than that of MORB and would be higher than that of the Shodo-Shima HMA, we supposed the degree of partial melting of the Osaka HMAs to be $15 \%$. The residual phase assemblages of the Yamato Basin basalt, Osaka HMA and Shodo-Shima HMA were assumed to be harzburgitic, hartzburgitic and lherzolitic, respectively based on high-pressure experiments (Tatumi, 1981, 1982; Wilson, 1989).

The REE concentrations of the asthenospheric component and pre-existing mantle are calculated by an equation assuming equilibrium batch melting (Shaw, 1970) with the above conditions. The calculated preexisting mantle is mixed with an asthenospheric component. This mixture induces the equilibrium batch melting (Shaw, 1970) with a $10 \%$ degree of partial melting and lehrzolitic residual phase assemblage to produce the Shodo-Shima HMAs or basalts. It must be noted that this simplified calculation for the pre-existing 


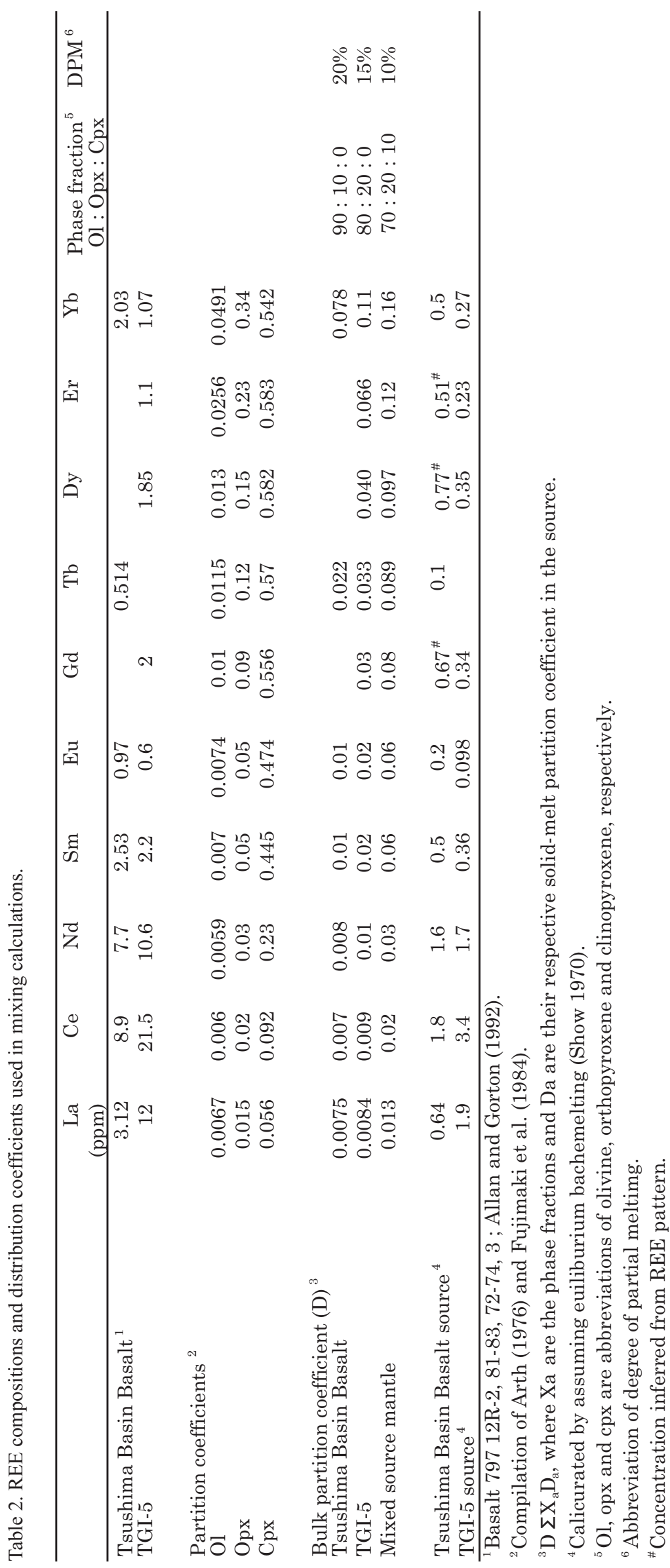


mantle contains a slab-derived component. Details of the calculation conditions are listed in Table 2.

The results of the calculation indicate that the mixing of the $30 \sim 70 \%$ asthenospheric component with the $70 \sim 30 \%$ pre-existing mantle material can reproduce the REE characteristics of SD261 and SDSYB in the Shodo-Shima area (Fig. 3). This wide variation in the results is probably caused by the following simple assumptions: the rough estimation of degrees of partial melting, difficulty to estimate the chemical composition of the asthenospheric material and uncertainty of the amount of slab-derived component in their magma source materials. In particular, the assumption about the amount of slab-derived components should contribute to the wide variation of the estimations because the amount of slab-derived component in the calculated Shodo-Shima magma composition is diluted by the addition of the asthenospheric component during the calculations. This uncertainty, however, can be tested by making a comparison between SD261 and SDSYB because Shimoda et al. (1998, 2003) demonstrated that the chemical compositions of magma source materials of SD261 and SDSYB before the addition of slab-derived components were identical, and the compositional difference between these magmas was produced by the different amount of added slab-derived components in their magma source materials. As shown in Fig. 3, the difference in REE patterns of SD261 and SDSYB is smaller than that in TGI-5 and SD261/SDSYB. Therefore the replacement of the pre-existing mantle wedge by the asthenospheric material can account for the REE patterns of the Setouchi HMAs and basalt.

Terakado et al. (1997) have reported that isotopic compositions of silicic rocks shifted from enriched to depleted during the Japan Sea opening in the SW Japan arc. Furthermore, it has been reported that the stress gradient in the Setouchi region during the rotational movement of SW Japan (Tatsumi et al., 2001) may be caused by the asthenospheric convection associated with the backarc opening (Tatsumi and Tsunakawa, 1992). These geochemical and geophysical constraints suggest that the SW Japan mantle wedge suffered a compositional change by an asthenospheric component related to the Japan Sea opening, which induced the rotational movement of SW Japan. This replacement raised the geothermal gradient beneath the area to induce the magmatism in the SW Japan arc.

\section{Conclusions}

The REE concentrations of the selected primitive Setouchi volcanic rocks were determined. The CI chondrite normalized REE pattern of the HMA from the Osaka area is different from that from the Shodo-Shima

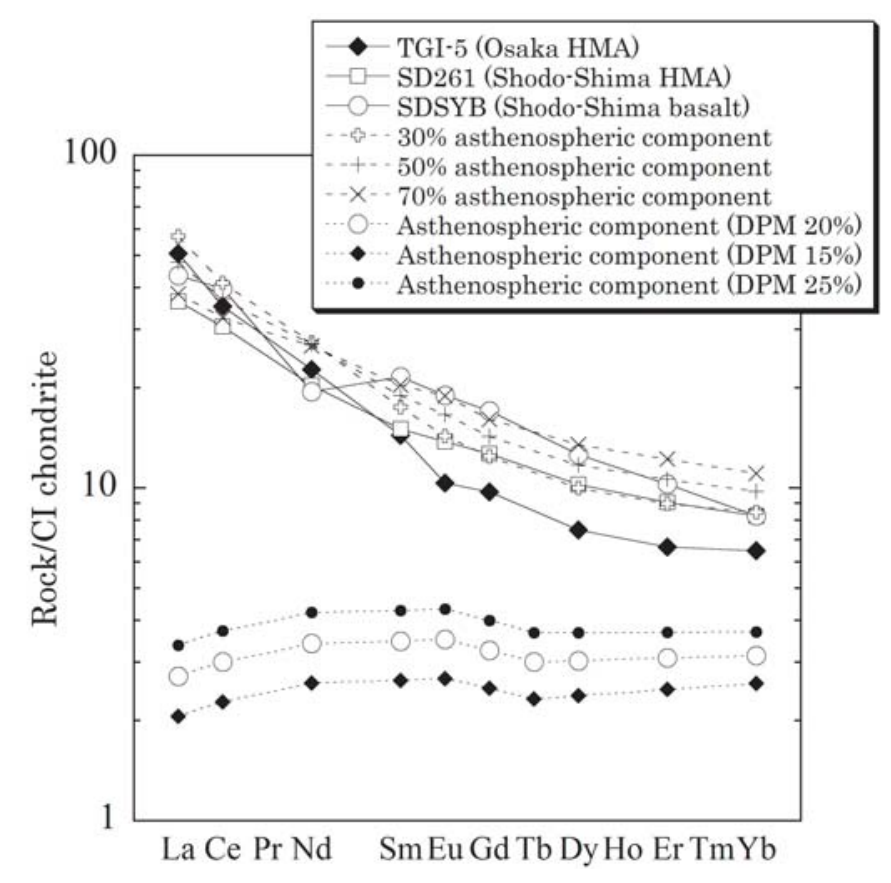

Fig. 3. Results of the mixing calculation. Details are shown in Table 2. The REE compositions of the asthenospheric components were determined with Yamato basin basalt and degrees of partial melting (DPM) of $15 \%, 20 \%$ and $25 \%$. Numbers displayed in percentage indicate the present asthenospheric material $(\mathrm{DPM}=20 \%)$ in the mixture.

area, i.e., the Osaka HMA has a higher LREE and lower HREE concentrations than the Shodo-Shima HMA. This is inconsistent with the estimated degree of partial melting. One of the possible explanations for the REE compositions is the mantle compositional change during the rotational movement of the SW Japan arc sliver because (1) a high temperature related to the Japan Sea opening is essential to the Setouchi magmatism and (2) heat is transported by material migration in the asthenosphere. In order to examine the mantle compositional change, mixing calculations were conducted. The result indicates that the mixing of $30-70 \%$ of asthenospheric component with $70-30 \%$ of pre-existing mantle material can reproduce the REE patterns of the Shodo-Shima HMA and basalt. This result suggests a mantle compositional shift. To understand the series of tectonic events systematically, i.e., the Japan Sea opening, rapid rotation of the SW Japan arc sliver and earlier magmatism in the Osaka area than that in the Shodo-Shima area, the most likely scenario would be the replacement of the mantle wedge by an asthenospheric material related to the backarc opening.

Acknowledgement- We thank Dr. Y. Tatsumi, Dr. K. Uto, Prof. S. Nohda, Dr. M. Ogasawara and Dr T. Sumii for useful discussions. We are grateful to Dr. Y. Tatsumi for providing samples. We are indebted 
to Dr. N. Geshi for critical and constructive comments.

\section{References}

Allan, J. and Gorton P. (1992) Geochemistry of igneous rocks from Leg127 and 128, Sea of Japan. Proc. ODP Sci. Res., 127/128, 905-929.

Arth J. P. (1976) Behavior of trace elements during magmatic processes- asummary of theoretical models and their apprications. Jour. Reserch U.S. Geol. Survey, 4, 41- 47.

Fujimaki H., Tatsumoto M. and Aoki K. (1984) Partition coefficients of Hf, $\mathrm{Zr}$ anr REEbetween phenocrysts and groundmasses. J Geophys Res., 89, supplements, B662-B672.

Iwasaki K. and Haraguchi H. (1988) Determination of rare earth elements in geological samples by inductivelycoupled plasma atomic emission spectrometry after oxalate coprecipitation and cation-exchange column. Anal. Chim. Acta., 208, 163-172.

Ishizaka, K. and Tatsumi, Y. (1985) Abundances of rare earth elements and other trace elements of so-called Setouchi volcanic rocks. Earth Science Report of College of Liberal Art and Sciences, Kyoto Univ., 20, 54-70 (in Japanese).

Kaneoka I., Notsu K., Takigami Y., Fujioka K. and Sakai H. (1990) Constraints on the evolution of the Japan Sea based on ${ }^{40} \mathrm{Ar}-{ }^{39} \mathrm{Ar}$ ages and $\mathrm{Sr}$ isotopic ratios for volcanic rocks of Yamato seamount chain in the Japan Sea. Earth.Planet. Sci. Lett., 97, 211-225.

Kaneoka I., Takigami Y., Takaoka N., Yamashita S. and Tamaki K. (1992) ${ }^{40} \mathrm{Ar}-{ }^{39} \mathrm{Ar}$ analysis of volcanic rocks recovered from Japan Sea floor: constraints on the age of formation the Japan Sea. Proc. ODP Sci. Res., 127/128, 819-836.

Mysen B O. and Kushiro I. (1977) Compositional variations of coexisting phases with degree of partial melting of peridotite in upper mantle. Am. Mineral., 62, 843-865.

Okino K., Shimakawa Y. and Nagaoka S. (1994) Evolution of the Shikoku Basin. J Geomagn. Geoelectr., 46, 463-479.

Otofuji Y., Itaya T. and Matsuda T. (1991) Rapid rotation of southwest Japan- paleomagnetism and K-Ar age of Miocene volcanic rocks of southwest Japan. Geophys. J. Int., 105, 397-405.

Otofuji Y., Matsuda T. and Nohda S. (1985) Opening mode of the Japan Sea inferred from paleomagnetism of the Japan arc. Nature, 317, 603-604.

Shaw H. R. (1970) Trace element fractionation during anatexis. Geochim. Cosmochim. Acta., 34, 237-243..

Shimoda G. and Tatsumi Y. (1999) Generation of rhyolite magmas by melting of subducting sediments in ShodoShima island, Southwest Japan, and its bearing on the origin of high-Mg andesites. The Island Arc, 8, 383392.
Shimoda G., Tatsumi Y., Nohda S., Ishizaka K. and Jahn B.M. (1998) Setouchi high-Mg andesites revisited: geochemical evidence for melting of subducting sediments. Earth. Planet. Sci. Lett., 160, 479-492.

Shimoda G., Tatsumi Y. and Morishita Y. (2003) Behavior of subducting sediments beneath an arc under high geothermal gradient; Constraints from the Miocene SW Japan arc. Geochem. J., 37, 503-518.

Shinjoe H. (1997) Origin of the granodiorite in the forearc region of southwest Japan; Melting of the Shimanto accretionary prism. Chem. Geol., 134, 237-255

Sun S.-s. and McDonough W.F. (1989) Chemical and isotopic systematics of oceanic basalt: implications for mantle composition and processes. In Saubders A.D., Norry M.J. eds., Magmatism in Ocean Bains (Geological Society Special Publ.), 313-345.

Tamaki K. (1995) Opening tectonics of the Japan Sea. In Taylor B. eds., Back Arc Basin (Plenum Press), 407420.

Tamaki K., Suyehiro K., Allan J., Ingle C.J. and Piscitto K.A. (1992) Tectonic synthesis and implications of Japan Sea ODP drilling. Proc. ODP Int. Rep., 127, 13331348.

Tatsumi Y. (1981) Melting experiment on a high-magnesian andesite. Earth. Planet. Sci. Lett., 54, 357-365.

Tatsumi Y. (1982) Origin of high-magnesian andesites in the Setouchi volcanic belt, southwest Japan, II. Melting phase relations at high pressures. Earth. Planet. Sci. Lett., 60, 305-317.

Tatsumi Y. and Maruyama S. (1989) Boninites and high$\mathrm{Mg}$ andesite: tectonics and petrogenesis. In Crawford A.J. eds., Boninites and Related rocks (Unwin Hyaman), 50-70.

Tatsumi Y. and Tsunakawa H. (1992) Cenozoic volcanism, stress gradient at back-arc opening in the North Island, New Zealand: Origin of Tanpo-Rotoruna Depression. The Island Arc, 1, 40-50.

Tatsumi Y., Ishikawa N., Anno K., Ishizaka K. and Itaya T. (2001) Tectonic setting of high-Mg andesite magmatism in the SW Japan arc: K-Ar chronology of the Setouchi volcanic belt. Geophys. J. Int., 144, 625631.

Terakado Y., Fujitani T. and Walker R.J. (1997) Nd and Sr isotopic constraints on the origin of igneous rocks resulting from the opening of the Japan Sea, southwestern Japan. Contrib. Mineral. Petrol., 411, 783786.

Tommasi A., Gibert B., Seipold U. and Mainprice D. (2001) Anisotropy of thermal diffusivity in the upper mantle. Contrib. Mineral. Petrol.. 129, 75-86.

Wilson M. (1989) Igneous petrogenesis (Chapman \& Hall), 466p.

Received April 7, 2004

Accepted May 27, 2004 


\section{瀬戸内高マグネシア安山岩及び玄武岩の希土類元素組成： \\ 日本海拡大時におけるマントルウエッジの組成変化に関する示唆}

\section{下田 玄·長井 正博·森下 祐一}

\section{要 旨}

日本海拡大が西南日本のマントルウエッジに及ぼした影響について評価するために、瀬戸内火山岩類の初生的な高マグ ネシア安山岩 (HMA) と玄武岩について希土類元素を測定した。噴出年代の古い大阪地域のHMA (13.9 Ma) は、噴出年代 の若い小豆島地域のHMA (12.7 Ma)に比べ、軽希土類元素の濃度が高く、かつ重希土類元素濃度が低い。この希土類元素 パターンの特徴を説明する為に、混合計算を行った。その結果、30〜 70\%のアセノスフェリック成分 (MORB source like materials) と、大阪地域のHMAから見積もられたマントル成分 70 〜 $30 \%$ が混合すれば、小豆島HMAと玄武岩の希土類元素 パターンが説明できることが解った。この結果は、日本海拡大時にアセノスフェアーが、西南日本のマントルウエッジに貫入し たことを示唆する。すなわち、高温のスラブの沈み込みとともに、高温のアセノスフェアーの流入が、この地域の異常な高温状 態を達成した可能性がある。この観点から見ると、瀬戸内地域や外帯に拈ける火成活動の成因、西南日本の回転、日本海拡 大という一連の現象が、整合的に理解できる。 